\title{
Isolated Hypoglossal Nerve Palsy as an Early Symptom of a Granular Cell Tumor
}

\author{
Juliana Lemound ${ }^{1, *(0)}$, Dimitrios Papadimas ${ }^{2}$, Sabine Skodda ${ }^{3}$, Andrea Tannapfel ${ }^{4}$, Anriy Alekseyev ${ }^{5}$ \\ and Martin Kunkel ${ }^{1}$
}

1 Department of Oral and Maxillofacial Surgery, Ruhr University Knappschaftskrankenhaus Bochum, 44892 Bochum, Germany; martin.kunkel@kk-bochum.de

2 Department of Oral and Maxillofacial Surgery, Klinikum Saarbrücken, 66119 Saarbrücken, Germany; dimitriospapadimas1980@gmail.com

3 Department of Neurology, Ruhr University Knappschaftskrankenhaus Bochum, 44892 Bochum, Germany; sabine.skodda@kk-bochum.de

4 Department of Pathology, University of Bochum Medical Center, Ruhr University Klinikum Bergmannsheil Bochum, 44789 Bochum, Germany; andrea.tannapfel@pathologie-bochum.de

5 Department for Radiology, Krankenhaus Wermelskirchen, 42929 Wermelskirchen, Germany; alekseyev@krankenhaus-wermelskirchen.de

* Correspondence: juliana.lemound@kk-bochum.de

check for updates

Citation: Lemound, J.; Papadimas, D.; Skodda, S.; Tannapfel, A.; Alekseyev, A.; Kunkel, M. Isolated Hypoglossal Nerve Palsy as an Early Symptom of a Granular Cell Tumor. Int. J. Environ. Res. Public Health 2022, 19, 2690. https://doi.org/10.3390/ ijerph19052690

Academic Editors: Marcel Hanisch and Lauren Bohner

Received: 25 December 2021

Accepted: 22 February 2022

Published: 25 February 2022

Publisher's Note: MDPI stays neutral with regard to jurisdictional claims in published maps and institutional affiliations.

Copyright: () 2022 by the authors Licensee MDPI, Basel, Switzerland. This article is an open access article distributed under the terms and conditions of the Creative Commons Attribution (CC BY) license (https:// creativecommons.org/licenses/by/ $4.0 /)$.

\begin{abstract}
Background: Hypoglossal nerve palsy (HNP) is rather common as a neurological disease. However, as an isolated nerve palsy it is an exceedingly rare phenomenon and points at local pathologies along the peripheral course of the nerve. In this communication we report a granular cell tumor (GCT) arising in the submandibular segment of the hypoglossal nerve. Case-Report: Spontaneous isolated HNP was recognized in a female patient. First line MR-imaging identified a clivus-chordoma. However, involvement of the hypoglossal nerve was highly unlikely according to MR-findings. Finally, ultrasonographic investigation revealed a small submandibular mass which, at histological examination, turned out to be a granular cell tumor arising within the hypoglossal nerve. Conclusions: This is the report of an extremely rare GCT originating within the 12th cranial nerve. The case illustrates that isolated motoric cranial nerve palsy may result from this rare tumor entity. This report also points out the diagnostic value of a simple ultrasonographic investigation to depict pathologic lesions of the submandibular space.
\end{abstract}

Keywords: granular cell tumor; Abrikossoff; hypoglossal nerve; nerve palsy; tongue atrophy

\section{Introduction}

Spontaneous isolated hypoglossal nerve palsy (HNP) is an exceedingly rare phenomenon and even when claimed to be isolated, detailed case reports most often describe either pain, meningeal signs and symptoms or cerebral and/or ocular ischemia [1-6]. This scarcity may be attributed to the close proximity of numerous important anatomical structures, which typically cause additional collateral symptoms rather than an isolated complaint. While quite common as part of neurological diseases involving the medulla oblongata, isolated hypoglossal palsy is rare and mostly indicative of local pathologies along the peripheral path of the nerve. Tumors or metastases of the skull base account for a major part of isolated HNP [7,8], as well as vascular pathologies, mostly internal carotid artery aneurysm or dissection [9-11]. A small fraction of cases are due to miscellaneous causes as dural arteriovenous fistulas [12], posterior fossa arachnoid cysts [13,14] and atlanto-occipital joint synovial cysts $[3,15,16]$. In addition, traumatic HNP has been described along with transoral intubation [17-20] and laryngeal mask application [21,22].

To the best of our knowledge, HNP caused by Abrikossoff's tumor has been documented so far only by Xiang et al., 2016 [23]. Thus, we report a further rare finding of an 
isolated unilateral hypoglossal nerve paralysis caused by a granular cell tumor arising in the submandibular segment of the hypoglossal nerve.

\section{Case Report}

\subsection{Clinical Findings and Imaging}

The patient referred to our hospital was a 48-year-old Caucasian female who (as a former health care professional) noticed ongoing painless tongue dysfunction for about 6 months. On hospital admission, physical examination revealed deviation of the tongue to the left and ipsilateral atrophy as the typical feature of left-sided hypoglossal nerve palsy (Figure 1). There were no other clinical signs and symptoms, neither on neurological nor on maxillofacial examination. Past medical history included hypothyroidism and a fibroadenoma of the left breast. Maxillofacial trauma has not occurred and neither orotracheal intubation, previous regional surgery nor any interventional procedures have been performed prior to the onset of the symptoms.

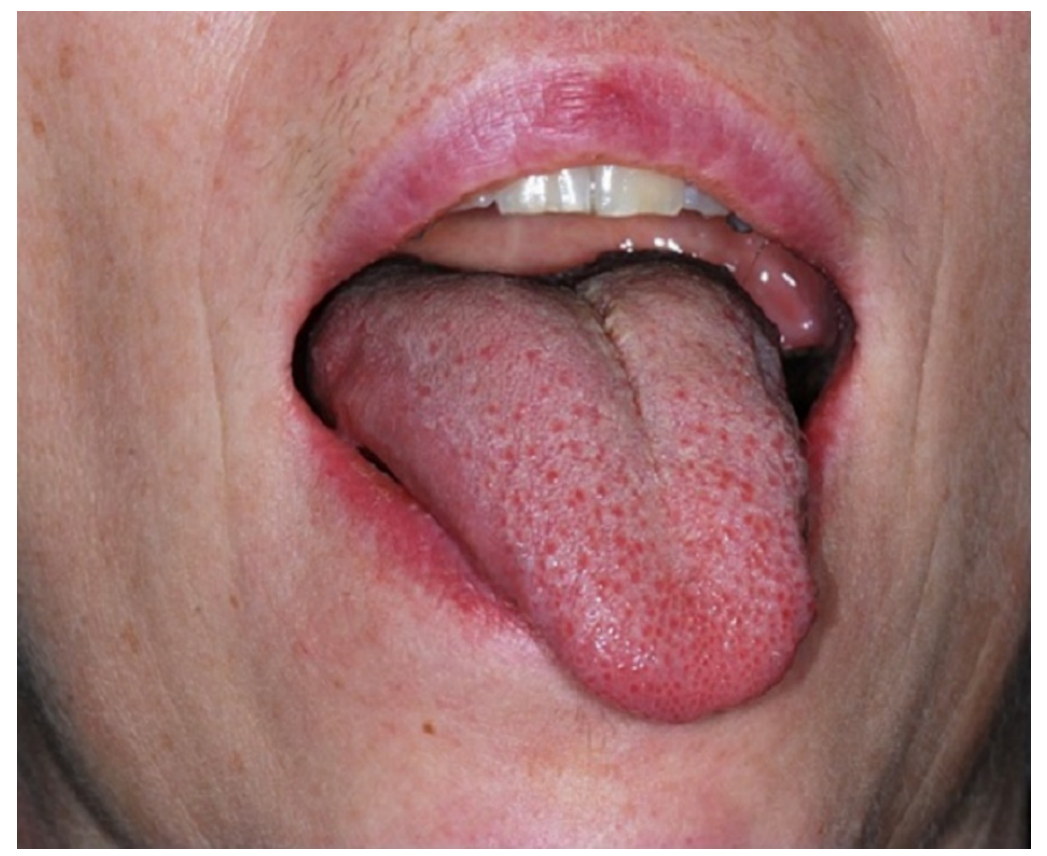

Figure 1. The initial clinical investigation shows a marked deviation of the tongue to the left as the typical feature of a left-sided hypoglossal nerve palsy.

Based on the initial neurological examination, an MRI of the neurocranium was performed. MRI imaging revealed an inhomogeneous, partly cystic, irregular, contrastaffinity lesion in the clivus with erosion of the cortical bone and incipient growth into the prepontine cistern, outside of brain parenchyma, suspected of a chordoma (Figure 2A,B). This was confirmed in cranial computed tomography in the bone window. No evidence of pathologies in the brainstem and in the cisternal course of the hypoglossal nerve up to the entrance into the hypoglossal canal were found. It was therefore not possible to determine any spatial relationship between the chordoma and the brainstem or the cisternal course of the hypoglossal nerve (Figure 2A,B). Thus, the chordoma could not be considered as the cause of palsy of the 12th cranial nerve.

Consequently, in addition to the MRI of the neurocranium, an ultrasound examination was performed to clarify the morphological status of the hypoglossal nerve in its extracranial course. In the ultrasound scan (Figure 3A,B) was identified as a well-defined, rather homogeneous ovoid tumor measuring $14 \times 7 \times 6 \mathrm{~mm}$ along the path of the hypoglossal nerve, protruding into the submandibular space but clearly demarcated from the sub- 
mandibular gland. Color flow mapping could not depict any vascular hilus structure but showed small vessels at the surface of the lesion. The nodal status of the neck was negative.
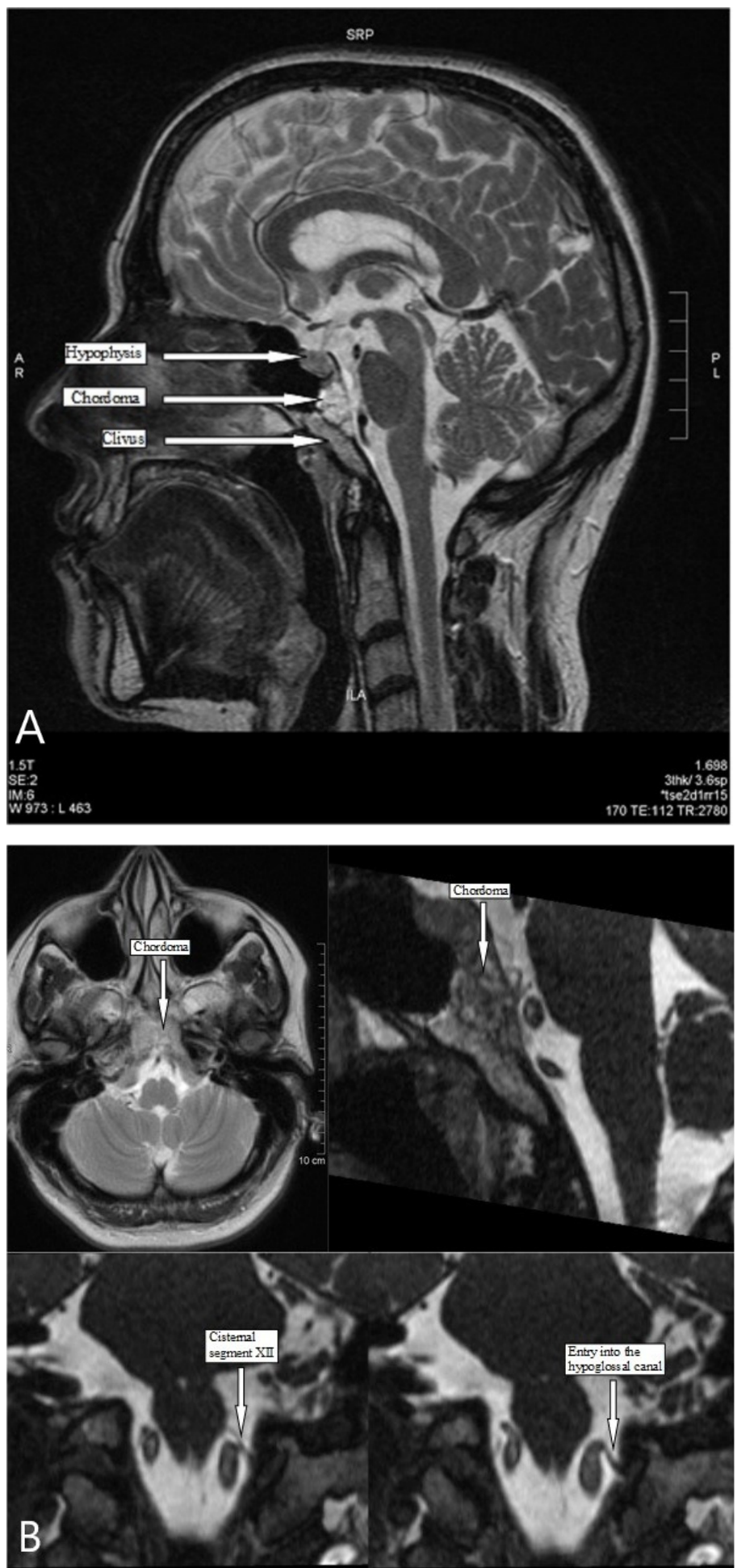

Figure 2. (A) MR-imaging, sagittal plane: Chordoma in the clivus area. (B) Cisternal segment and entry of the 12th cranial nerve into the hypoglossal canal. 

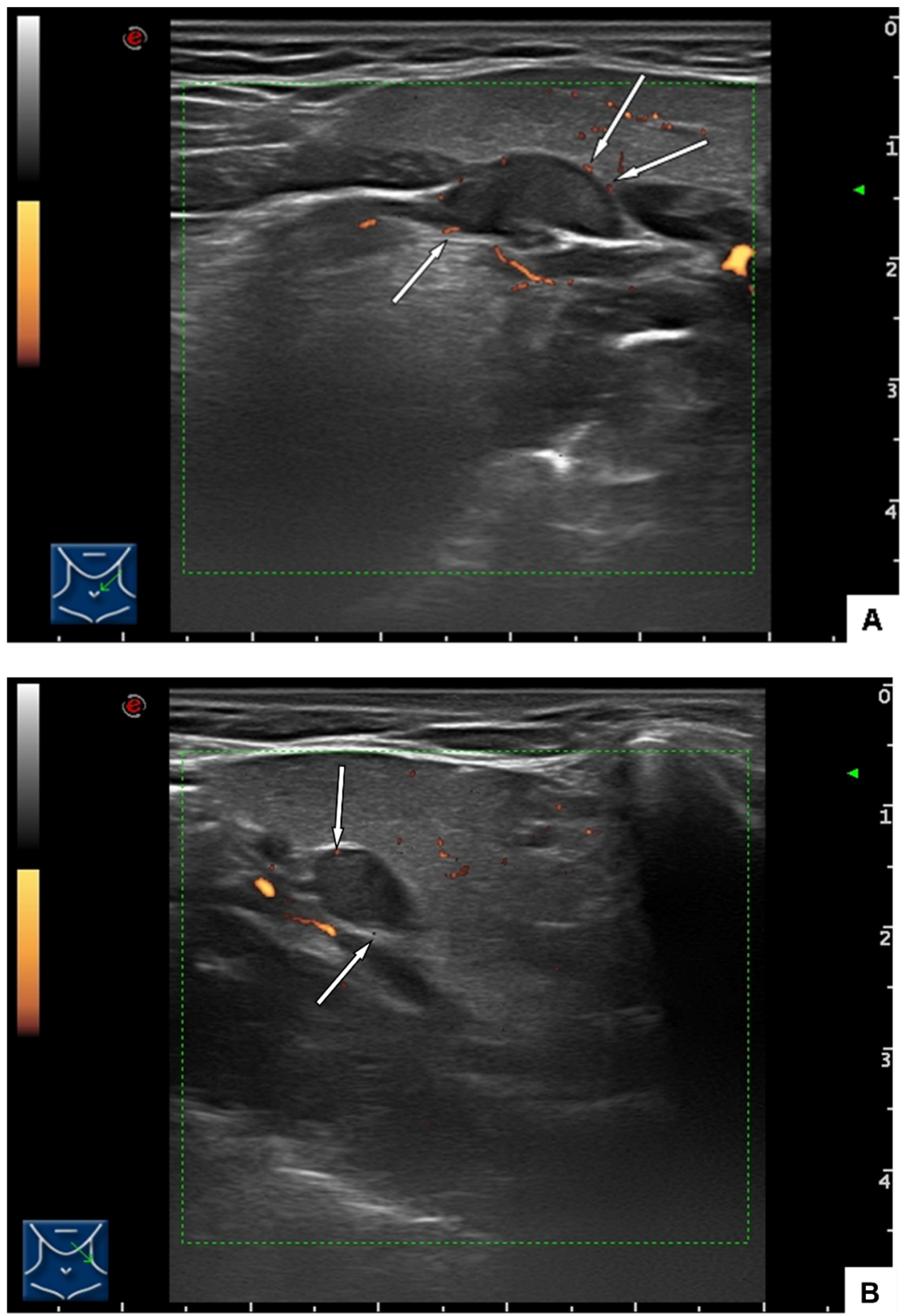

Figure 3. (A) Ultrasound findings: The rather homogeneous tumor is clearly demarcated from the surrounding tissues. Arrows indicate the position of vessels at the tumor surface. (B) Transverse view.

The ultrasound examination was explanatory for a peripheral hypoglossal nerve lesion, further examinations were not necessary.

\subsection{Surgical Treatment and Outcome}

The mass was excised by a submandibular approach. Consistent to the preoperative ultrasonographic findings the lesion showed prominent superficial vessels (Figure 4A). The dissection finally exposed a yellowish tumor which appeared as a fusiforme swelling of the nerve, measuring about $15 \mathrm{~mm}$. Since the tumor could not be separated from the nerve fascicles, complete surgical excision was performed (Figure 4B), followed by a simultaneous end to end anastomosis of the hypoglossal nerve. The postoperative clinical course was uneventful with partial recovery of the motoric function. There was no recurrence in the 20 months of follow up. 

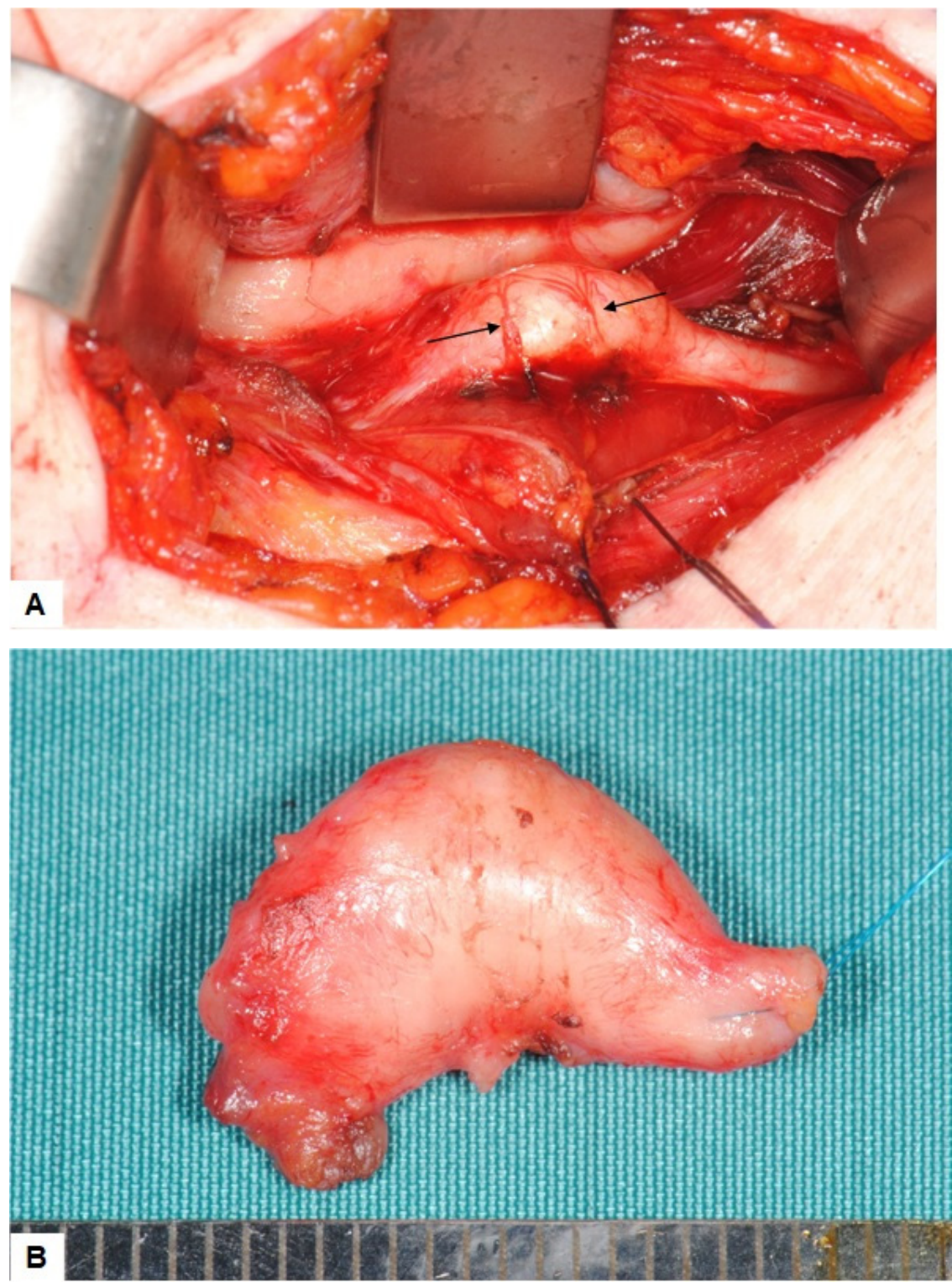

Figure 4. (A) Intraoperative findings: The tumor appears as a swelling of the hypoglossal nerve. As suggested by ultrasound findings, small vessels cross the surface. No adhesion to the surrounding tissues and especially no adhesion to the mylohyoid muscle is found. (B) Resection specimen: The tumor appears fully encapsulated by the perineurium When sectioned, there is no demarcation between the nerve and the tumor.

Histopathologic analysis showed a well-defined lesion consisting of clusters of polygonal cells with small nuclei and a characteristic granular eosinophilic cytoplasm. The HE morphology was suggestive of a granular cell tumor (GCT). Immunohistochemistry confirmed cytoplasmic granules to be strongly positive for S-100, typical for a GCT. The architecture of the hypoglossal nerve was completely disrupted, the nerve fascicles were split up. High-power magnification revealed diffuse infiltration of the nerve fascicles by S-100 positive granular cells (Figure 5A-D). 

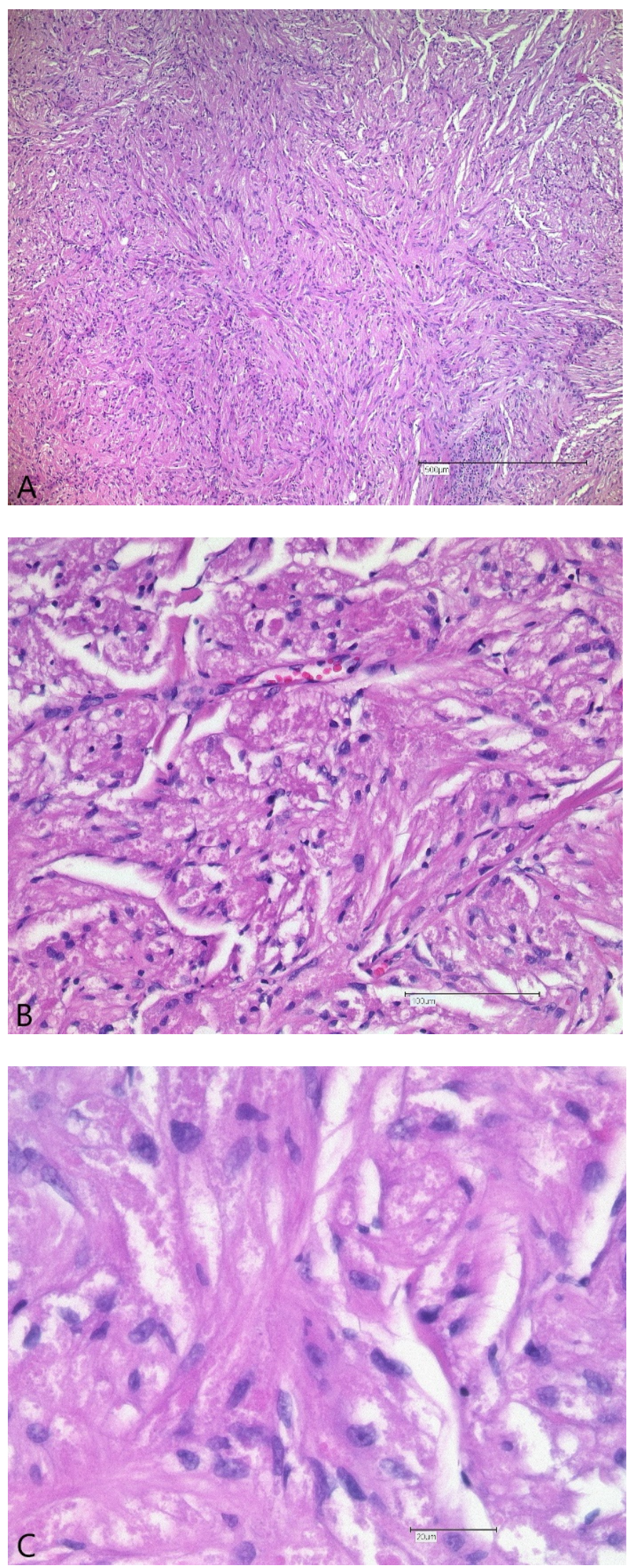

Figure 5. Cont. 


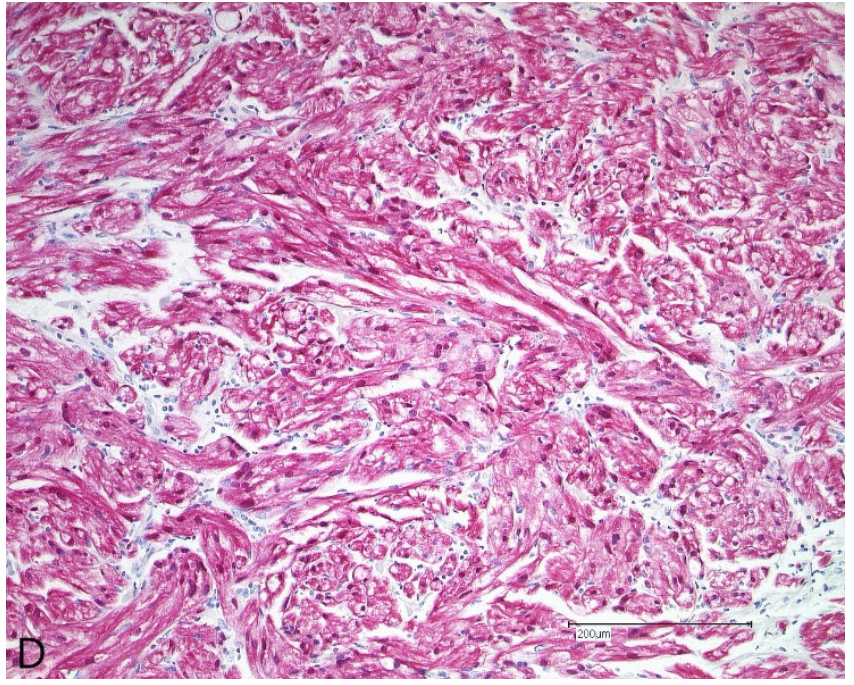

Figure 5. Histological findings: The granular appearance of the cytoplasm as to be seen at higher magnification is the typical morphological feature of GCT. H/E-staining, scale bars $500 \mu \mathrm{m}$ (A), zoomed-in views $100 \mu \mathrm{m}$ (B) and $20 \mu \mathrm{m}$ (C). The tumor consists of aggregates of granular cells staining intensively positive for S100 ((D): immunohistology for S-100). Granular cell infiltration and disruption of the nerval structures can be seen on both H/E-staining and after S-100 staining.

A few weeks later the pathologic mass in the clivus area was treated by a transnasaltranssphenoidal resection followed by subsequent proton irradiation. The histological analysis confirmed a clivus chordoma.

\section{Discussion}

Granular cell tumor is a rare neoplasm first described 1926 by the pathologist Dr. Alexei Abrikossoff [24]. The typical clinical appearance is a slowly growing, usually painless mass [25-27]. Although mostly benign, 1-2\% of all GCT show a malignant phenotype arising either from a long-standing benign GCT or (mostly) de novo [28,29]. The GCT have a higher incidence during the third through the sixth decades of life and show a female preponderance in oral subsites [29-33]. About one half of the cases involve the head and neck, where it is predominantly found in the anterior two-thirds of the oral tongue [31,33-35]. Some cases were described in the gastrointestinal tract [36,37], in the upper respiratory tract [38], in the lower respiratory tract [39], in the breast [40] and extremely rare in peripheral nerves [41]. Peripheral occurrence has been reported for tibial [32], radial, ulnar [25,42], median, sciatic [28], sural [41] and digital nerves [43,44], all together either sensory or mixed type nerves. Regarding cranial nerves, involvement of trigeminal and recurrent laryngeal nerves has been found [32]. In contrast to this, 2016 a GCT of the hypoglossal nerve, presenting as an isolated unilateral hypoglossal nerve paralysis with tongue muscle atrophy has been reported by Xiang et al. [23]. In this case, the ca. $50 \mathrm{~mm}$ large tumor was identified in MRI as a non-encapsulated hypo signal mass posterior to the submandibular gland [23]. In our case, the $15 \mathrm{~mm}$ large tumor was diagnosticated by ultrasound scan, which was performed additional to MRI of the neurocranium.

It seems noteworthy, that GCT's are generally considered to remain clinically silent [31] except for signs and symptoms caused by compression effects on the surrounding tissue or organs. In our case, however, the GCT caused highly specific symptoms such as a distinct motorial palsy and consecutive atrophy of the tongue resulting from the infiltration of the hypoglossal nerve. Similar clinical characteristics have only been reported for the rare cases, where GCT's involve large peripheral nerves [25,45].

In case of isolated hypoglossal palsy, the recommended diagnostic workflow includes MRI of the neurocranium to identify pathologies in the brainstem and in the cisternal course of hypoglossal nerve. To investigate the peripheral extracranial course of the 
hypoglossal nerve ultrasound scan or MRI imaging of soft tissues of the neck and mouth floor are available.

The histogenesis of granular cell tumors has been a source of controversy for many decades. Due to the common intermuscular location and the cellular similarity between GCT and skeletal muscles, it was initially suggested that the tumor originates from embryonic myoblasts $[30,31,46]$. Pathological investigations including electron microscopic and immunohistochemical studies, however, failed to demonstrate a muscle cell origin and favored-due to the typical S-100 positivity-a neural derivation of the GCT, most likely from the Schwann cells $[25,29,31,32,41,47,48]$.

Our findings are in line with the later hypothesis. The tumor was completely embedded in the perineurium without adherence or even contact to the neighboring muscles, thus, lacking signs of external infiltration. Despite this clear demarcation against surrounding tissue, virtually any fascicle of the nerve showed extensive infiltration by granular cells. Both the intraoperative and morphological features favor a neural derivation of the GCT.

\section{Conclusions}

In this report we present a rare case of a GCT originating within the hypoglossal nerve. The case illustrates that isolated motoric cranial nerve palsy may result from this rare tumor entity. The case also points out the diagnostic value of a simple ultrasound investigation to depict pathologic lesions of the submandibular space.

Author Contributions: Conceptualization, methodology and software J.L. and M.K.; validation, J.L., D.P., S.S., A.T., A.A. and M.K.; formal analysis, J.L., D.P. and M.K.; investigation, J.L., A.T., A.A., M.K.; resources, J.L. and M.K.; data curation, J.L.; writing — original draft preparation, J.L., D.P. and M.K.; writing-review and editing, J.L.; visualization, J.L.; supervision, A.T. and M.K.; administration, J.L.. All authors have read and agreed to the published version of the manuscript.

Funding: This research received no external funding.

Institutional Review Board Statement: A case report did not require ethical review and approval of our ethics committee of Ruhr university Bochum.

Informed Consent Statement: Written informed consent has been obtained from the patient to publish this paper.

Data Availability Statement: The data are available upon request.

Conflicts of Interest: The authors declare no conflict of interest.

\section{References}

1. Boban, M.; Brinar, V.V.; Habek, M.; Rados, M. Isolated hypoglossal nerve palsy: A diagnostic challenge. Eur. Neurol. 2007, 58, 177-181. [CrossRef]

2. Alharbi, F.A.; Lenarz, T.; Stoever, T. A case of unilateral hypoglossus nerve palsy associated with chordoma in the region of clivus. Eur. Arch. Oto-Rhino-Laryngol. 2009, 266, 2001-2003. [CrossRef] [PubMed]

3. Hewett, R.M.; Stewart, G.E. Neurological picture. Isolated hypoglossal nerve palsy caused by synovial cyst. J. Neurol. Neurosurg. Psychiatry 2011, 82, 376-377. [CrossRef] [PubMed]

4. Bryer, E.; Henry, D. Isolated hypoglossal nerve palsy as a presenting symptom of metastatic peripheral T-cell lymphoma-Not otherwise specified (PTCL-NOS): A unique case \& a review of the literature. Int. J. Hematol. Oncol. 2018, 7, IJH03. [CrossRef] [PubMed]

5. Cant, A.; Collard, B. Oral medicine: Isolated unilateral hypoglossal nerve palsy. Br. Dent. J. 2018, 225, 95. [CrossRef]

6. Edizer, D.T.; Mercan, H.; Cansiz, H. Hypoglossal schwannoma presenting only with headache. J. Craniofac. Surg. 2010, 21, 261-262. [CrossRef]

7. Keane, J.R. Twelfth-nerve palsy. Analysis of 100 cases. Arch. Neurol. 1996, 53, 561-566. [CrossRef]

8. Khoo, S.G.; Ullah, I.; Wallis, F.; Fenton, J.E. Isolated hypoglossal nerve palsy: A harbinger of malignancy. J. Laryngol. Otol. 2007, 121, 803-805. [CrossRef]

9. Mokri, B.; Silbert, P.L.; Schievink, W.I.; Piepgras, D.G. Cranial nerve palsy in spontaneous dissection of the extracranial internal carotid artery. Neurology 1996, 46, 356-359. [CrossRef]

10. Binzer, S.; Petkova, V. 12th nerve palsy in a woman with extracranial internal carotid artery aneurysm. Ugeskr. Laeger 2020, 182, $1-3$. 
11. Koscielny, S.; Koch, J.; Behrendt, W. Aneurysma der A. carotis interna. Die besondere Differenzialdiagnose einer Parese der kaudalen Hirnnerven. HNO 2003, 51, 728-732. [CrossRef] [PubMed]

12. Combarros, O.; Alvarez de Arcaya, A.; Quintana, F.; Bèrciano, J. Parálisis del nervio hipogloso como forma de presentación de una fístula arteriovenosa dural de la fosa posterior. Neurologia 1998, 13, 260-262. [PubMed]

13. Cartwright, M.J.; Eisenberg, M.B.; Page, L.K. Posterior fossa arachnoid cyst presenting with an isolated twelfth nerve paresis. Case report and review of the literature. Clin. Neurol. Neurosurg. 1991, 93, 69-72. [CrossRef]

14. Tarantino, R.; Marruzzo, D.; Colistra, D.; Mancarella, C.; Delfini, R. Twelfth nerve paresis induced by an unusual posterior fossa arachnoid cyst: Case report and literature review. Br. J. Neurosurg. 2014, 28, 528-530. [CrossRef] [PubMed]

15. Mujic, A.; Hunn, A.; Liddell, J.; Taylor, B.; Havlat, M.; Beasley, T. Isolated unilateral hypoglossal nerve paralysis caused by an atlanto-occipital joint synovial cyst. J. Clin. Neurosci. 2003, 10, 492-495. [CrossRef]

16. Gassie, K.; Grewal, S.; Chen, S.G. Atlantooccipital Synovial Cyst with Isolated Hypoglossal Nerve Palsy: Case Report of Nonfusion Surgical Approach and Review of Literature. World Neurosurg. 2019, 126, 434-438. [CrossRef]

17. Hong, S.J.; Lee, J.Y. Isolated unilateral paralysis of the hypoglossal nerve after transoral intubation for general anesthesia Dysphagia 2009, 24, 354-356. [CrossRef]

18. Rubio-Nazábal, E.; Marey-Lopez, J.; Lopez-Facal, S.; Alvarez-Perez, P.; Martinez-Figueroa, A.; Del Rey Corral, P. Isolated bilateral paralysis of the hypoglossal nerve after transoral intubation for general anesthesia. Anesthesiology 2002, 96, 245-247. [CrossRef]

19. Schmidt, T.; Philipsen, B.B.; Manhoobi, Y.; Bruun Christiansen, E.L. Vagus and hypoglossus palsy after nasotracheal intubation and throat packing. Ugeskr. Laeger 2018, 180, $2-3$.

20. Ulusoy, H.; Besir, A.; Cekic, B.; Kosucu, M.; Geze, S. Transient unilateral combined paresis of the hypoglossal nerve and lingual nerve following intubation anesthesia. Bras. J. Anesthesiol. 2014, 64, 124-127. [CrossRef]

21. King, C.; Street, M.K. Twelfth cranial nerve paralysis following use of a laryngeal mask airway. Anaesthesia 1994, 49, 786-787. [CrossRef] [PubMed]

22. Tham, L.Y.; Beh, Z.Y.; Shariffuddin, I.I.; Wang, C.Y. Unilateral hypoglossal nerve palsy after the use of laryngeal mask airway (LMA) Protector. Korean J. Anesthesiol. 2019, 72, 606-609. [CrossRef] [PubMed]

23. Xiang, J.; Lao, I.W.; Ji, Q. Granular cell tumor of the hypoglossal nerve presenting with tonque atrophy and deviation: A case report. Int. J. Clin. Exp. Pathol. 2016, 9, 2504-2507.

24. Abrikossoff, A. Über Myome. Virchows Arch. Pathol. Anat. Physiol. Klin. Med. 1926, 260, 215-233. [CrossRef]

25. Papachristou, D.J.; Palekar, A.; Surti, U.; Cieply, K.; McGough, R.L.; Rao, U.N.M. Malignant granular cell tumor of the ulnar nerve with novel cytogenetic and molecular genetic findings. Cancer Genet. Cytogenet. 2009, 191, 46-50. [CrossRef] [PubMed]

26. Hyodo, M.; Sadamoto, A.; Murakami, S. Malignant granular cell tumour of the cervical sympathetic nerve trunk. J. Laryngol. Otol. 2001, 115, 833-835. [CrossRef]

27. Tsuchida, T.; Okada, K.; Itoi, E.; Sato, T.; Sato, K. Intramuscular malignant granular cell tumor. Skelet. Radiol. 1997, $26,116-121$. [CrossRef]

28. Hurrell, M.A.; McLean, C.; Desmond, P.; Tress, B.M.; Kaye, A. Malignant granular cell tumour of the sciatic nerve. Australas. Radiol. 1995, 39, 86-89. [CrossRef]

29. Mirza, F.N.; Tuggle, C.T.; Zogg, C.K.; Mirza, H.N.; Narayan, D. Epidemiology of malignant cutaneous granular cell tumors: A US population-based cohort analysis using the Surveillance, Epidemiology, and End Results (SEER) database. J. Am. Acad. Dermatol. 2018, 78, 490-497.e1. [CrossRef]

30. Marolleau, F.; Baert, F.; Mertens, V.; Ghillebert, G. Abrikossoff cell tumor of the oesophagus: A case report and review of the literature. Acta Clin. Belg. 2008, 63, 273-276. [CrossRef]

31. Ordóñez, N.G.; Mackay, B. Granular cell tumor: A review of the pathology and histogenesis. Ultrastruct. Pathol. 1999, $23,207-222$. [CrossRef] [PubMed]

32. Dogramaci, Y.; Kalaci, A.; Sevinc, T.T.; Hakverdi, S.; Canda, S.; Yanat, A.N. Granular cell tumor of the posterior tibial nerve as a rare cause of heel pain: A case report. J. Am. Podiatr. Med. Assoc. 2009, 99, 254-257. [CrossRef] [PubMed]

33. Brannon, R.B.; Anand, P.M. Oral granular cell tumors: An analysis of 10 new pediatric and adolescent cases and a review of the literature. J. Clin. Pediatr. Dent. 2004, 29, 69-74. [CrossRef] [PubMed]

34. Lack, E.E.; Worsham, G.F.; Callihan, M.D.; Crawford, B.E.; Klappenbach, S.; Rowden, G.; Chun, B. Granular cell tumor: A clinicopathologic study of 110 patients. J. Surg. Oncol. 1980, 13, 301-316. [CrossRef]

35. Charles, N.C.; Fox, D.M.; Glasberg, S.S.; Sawicki, J. Epibulbar granular cell tumor. Report of a case and review of the literature. Ophthalmology 1997, 104, 1454-1456. [CrossRef]

36. Butler, J.D.; Brown, K.M. Granular cell tumor of the extrahepatic biliary tract. Am. Surg. 1998, 64, $1033-1036$.

37. Billeret Lebranchu, V. La tumeur à cellules granuleuses. Epidémiologie de 263 cas. Arch. Anat. Cytol. Pathol. 1999, 47, 26-30.

38. Victoria, L.V.; Hoffman, H.T.; Robinson, R.A. Granular cell tumour of the larynx. J. Laryngol. Otol. 1998, 112, 373-376. [CrossRef]

39. Abdulhamid, I.; Rabah, R. Granular cell tumor of the bronchus. Pediatr. Pulmonol. 2000, 30, 425-428. [CrossRef]

40. Adeniran, A.; Al-Ahmadie, H.; Mahoney, M.C.; Robinson-Smith, T.M. Granular cell tumor of the breast: A series of 17 cases and review of the literature. Breast J. 2004, 10, 528-531. [CrossRef]

41. Daentzer, D.; Schmidinger, A.; Böker, D.-K. Atypical granular cell tumour of the sural nerve mimicking a Schwannoma. Acta Neurochir. 2003, 145, 1019-1020. [CrossRef] [PubMed] 
42. Dahlin, L.B.; Lorentzen, M.; Besjakov, J.; Lundborg, G. Granular cell tumour of the ulnar nerve in a young adult. Scand. J. Plast. Reconstr. Surg. Hand Surg. 2002, 36, 46-49. [CrossRef] [PubMed]

43. Weinreb, I.; Bray, P.; Ghazarian, D. Plexiform intraneural granular cell tumour of a digital cutaneous sensory nerve. J. Clin. Pathol. 2007, 60, 725-726. [CrossRef] [PubMed]

44. Bue, P.; Holck, S.; Holst-Nielsen, F. Granulaercelletumor lokaliseret til en fingernerve. Ugeskr. Laeger 1984, 146, $2319-2320$.

45. Toker, C. Neural origin of granular cell tumor. Mt. Sinai J. Med. 1974, 41, 655-657.

46. López-Jornet, P. Granular cell tumor of the tongue. N. Y. State Dent. J. 2008, 74, 71-72.

47. Mackenzie, D.J.; Klapper, E.; Gordon, L.A.; Silberman, A.W. Granular cell tumor of the biliary system. Med. Pediatr. Oncol. 1994, 23, 50-56. [CrossRef]

48. Sobel, H.J.; Marquet, E.; Avrin, E.; Schwarz, R. Granular cell myoblastoma. An electron microscopic and cytochemical study illustrating the genesis of granules and aging of myoblastoma cells. Am. J. Pathol. 1971, 65, 59-78. 